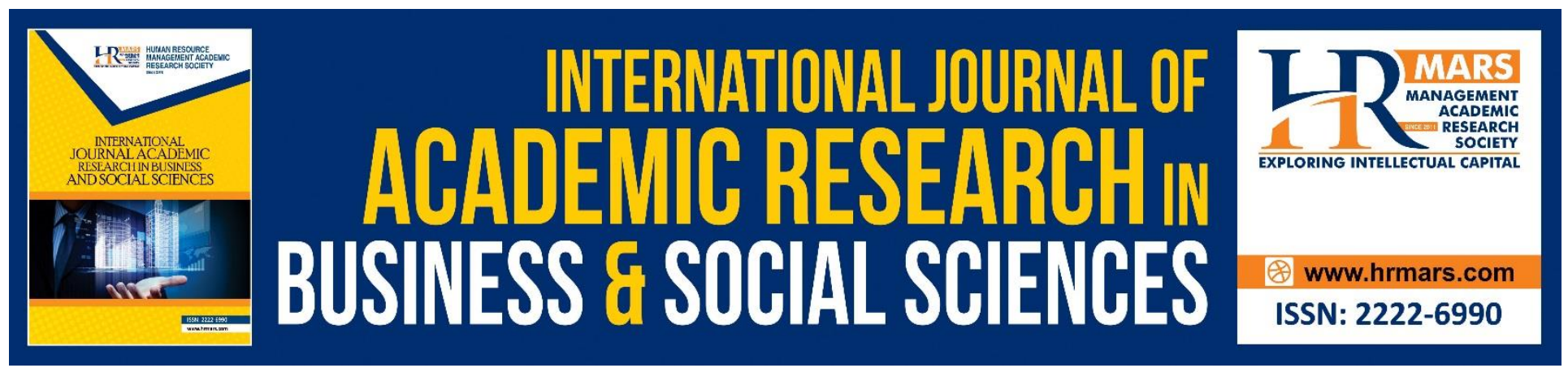

\title{
Factors that Influence Students' Perception towards Retailing as a Career
}

Mardhiah Kamaruddin, Raida Syahirah Ahmad Shukri, Nuur Arifah Azmi, Aimi Nadia Ibrahim @ Zakaria, Nik Noorhazila Nik Mud, Nur Ain Mahat

To Link this Article: http://dx.doi.org/10.6007/IJARBSS/v8-i9/4860 DOI: $10.6007 /$ IJARBSS/v8-i9/4860

Received: 22 August 2018, Revised: 16 Sept 2018, Accepted: 27 Sept 2018

Published Online: 09 Oct 2018

In-Text Citation: (Kamaruddin et al., 2018)

To Cite this Article: Kamaruddin, M., Shukri, R. S. A., Azmi, N. A., Zakaria, A. N. I. @, Mud, N. N. N., \& Mahat, N. A. (2018). Factors That Influence Students' Perception towards Retailing as a Career. International Journal of Academic Research in Business and Social Sciences, 8(9), 1508-1516.

Copyright: (c) 2018 The Author(s)

Published by Human Resource Management Academic Research Society (www.hrmars.com)

This article is published under the Creative Commons Attribution (CC BY 4.0) license. Anyone may reproduce, distribute, translate and create derivative works of this article (for both commercial and non-commercial purposes), subject to full attribution to the original publication and authors. The full terms of this license may be seen

at: http://creativecommons.org/licences/by/4.0/legalcode

Vol. 8, No. 9, September 2018, Pg. 1508 - 1516

Full Terms \& Conditions of access and use can be found at http://hrmars.com/index.php/pages/detail/publication-ethics 


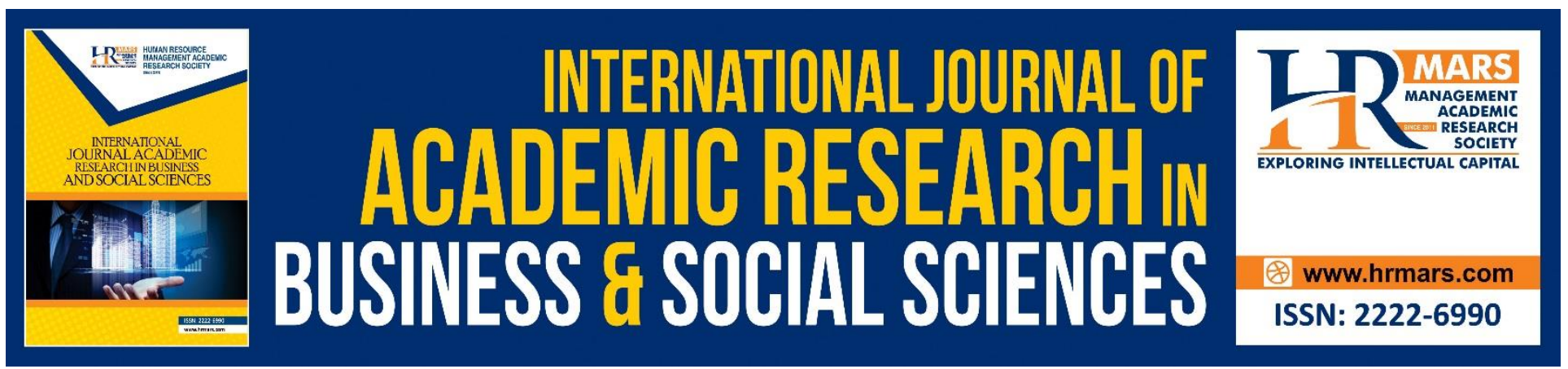

\title{
Factors That Influence Students' Perception towards Retailing as a Career
}

\author{
Mardhiah Kamaruddin, Raida Syahirah Ahmad Shukri, Nuur Arifah \\ Azmi, Aimi Nadia Ibrahim @ Zakaria, Nik Noorhazila Nik Mud, Nur \\ Ain Mahat
}

Faculty Entrepreneurship and Business, Universiti Malaysia Kelantan, Malaysia

\begin{abstract}
A study was conducted to identify the association between factors (interest, opportunity, social environment, and career flexibility) and students' perception towards retailing as a career in Universiti Malaysia Kelantan. The purpose of this study to determine which factors that significant with the students' perception towards retailing as career. Data were collected using questionnaires. 258 students from retailing course at Universiti Malaysia Kelantan were selected as respondents. Simple random sampling was applied to allow the researchers to collect the responses easily and quickly because of our population just in a small range. The study utilized descriptive analysis and multiple linear regression to analyze the data. From this research, the factors that significant were opportunity $(p=0.001, \beta=0.35)$, social environment $(p<0.001, \beta=0.15)$, and career flexibility $(p=0.001, \beta=0.29)$. Factors that associated with students' perception towards retailing were opportunity, social environment, and career flexibility.
\end{abstract}

Keywords: Retailing, Perception, Opportunity, Social Environment, and Career Flexibility

\section{Introduction}

Retailing is an inspiring industry because need strong chief and energetic employee and it is fast-moving (Suryanarayana \& Kumar). Retailing can create more jobs opportunity, especially to the low qualified individual because retailing is the emerging industry that provides an opportunity to help us from under to above poverty line (Suryanarayana \& Kumar).

Having a negative perception towards retailing may have a direct association to choose a career. Students impression in retailing linked with the negative environment like as boring routine (Lindblom et al., 2016). Because of that misunderstanding, some of the graduates not interested in the retail profession and more prefer to choose other careers (Lindblom et al., 2016). It can be more challenging to recruit current graduates for involving in the retailing industry (Lindblom et al., 2016). 
The retailing industry needed a person who can create sustainable profit to their company especially qualified people (Mokhlis, 2014b). A student who undergraduates in the business study should be attracting in the retailing industry because they may have high caliber (Mokhlis, 2014b). However, these graduates show reluctance to involve in the retailing sector after finish their study even though they have potential to become a success retail manager and can run their own business (Mokhlis, 2014b).

Retail programs are usually plural of many business universities, as they provide the opportunity to apply what they have learned in the classroom to the "real world" and the interest is an important factor that will prove in finding (Renko, Rasic, \& Petljak, 2016b). Students think that retail program only involves retailing and small shop and it was unfortunate when student show an opposition to work in the retailing business after graduation (Mokhlis, 2014a). The study reported that students do not really realize what a job in retailing entails. Past studies also show that students' perceptions of retail careers appear to be influenced by a company's image and types of the retail sector, with some sectors more highly rated by students as chosen career destinations than others (Renko et al., 2016b). Usually, we can see that most of the student chooses this program because they have background family, education or job satisfaction.

At the same time, they think that by involving in retailing, the salary that they will get will be in a small amount and it can give the problem because of the current economy trend in Malaysia. Students appear to associate a career in retailing as a primarily store-based and this is attributed with bad descriptors such as poor salary and long unsociable hours. Other than that, environment factor also can be the problem because we know that the generation now only wants to do the easy work. They also want to work at a place that gives the satisfaction, good facilities, and others. Most of them think that retailing only can work at a small place and cannot work at the company. Maybe they did not know what retail is and where they can work. Studies have found that Generation $Y$ wants a balance of personal and work goals, social networks and social environment at work, as well as moral training and development in an organization (Isaac \& Roger, 2016).

Lastly, what we can see is that some students do not engage in talks related to entrepreneurship and retailing. We know that the lecturer every course will provide lectures related to their course is no exception and also with retail course. We are aware that the lecturer has made various talks and from there we can see the involvement of students in attending the lecture. Being less involved, this will reduce further the knowledge of retailing and retailing think that no great career (A. Broadbridge, 2003). Then, most people think that it only involved a small shop because maybe they think that they cannot do at a large company. They also must think that retail only involves in retailing and take the experience with the small shop.

There are parts of university offered entrepreneurship programmed nowadays. This is because of less of occupied opportunities. When they offered this course for a student, it can help the student to become an entrepreneur and run their own business after graduates. Universiti Malaysia Kelantan one of the universities that offer entrepreneurship programmed for the student. 
One of the courses is Entrepreneurship of Retailing. Most of the student can't see the opportunities that have in this course for their career. This is because of negative perspective they get from the environment. So, this study will be conducted to determine factors that influence students' perception of retailing as a career.

\section{Methodology}

A cross-sectional study design was applied to test the hypotheses and respond to research questions in a more systematic way. This method used to identify the association between the factors which are interest, opportunity, social environment, career flexibility and students' perception towards retailing as a career. Descriptive research design also applied in this study which enabled to identify the descriptive analysis of the variables.

The target population was all the students from the retail course in Universiti Malaysia Kelantan year one until year four. The total population consists of 600 students in Universiti Malaysia Kelantan. The sampling frame for this study was the list of the retailing course student from the first year to the fourth year that has been sampled. Probability sampling method was applied for this study. A simple random sampling method was used to obtain the information from the respondents. This element does not have an equal chance of being selected. It is very economical and easily performed. All the retailing students year 1, 2, 3 and 4 was included in the study. The list of names of retailing students was obtained from Faculty Entrepreneurship and Business, Universiti Malaysia Kelantan. Then, simple random sampling was applied by generating random number using Microsoft excel and the list name will appear. After the list name appeared, we get their phone number by spread their name and WhatsApp Group for spreading the questionnaire in the Official Retail WhatsApp Group. After that, they will join the group that we create. After the respondent join the group, we will decide the place and time so that we can distribute the questionnaire to them.

The questionnaire was used in this study to collect information. This approach is the direct way for the researcher to obtain the information. For better understanding, the researcher clearly informed and explained about the objective of the research and any unclear question for the respondents.

We conducted a pre-test by distributed the questionnaire to the 5 lecturers in Universiti Malaysia Kelantan to answer the questionnaire. Those five respondents went through the cognitive interview session and was asked by the researcher if there were any words or phrases that are confusing, and how they understand the instructions of the questionnaire (Streiner et al., 2014). They also allowed to give opinion regarding the questionnaire. During pre-test phase, time taken by the respondents to complete the questionnaire was recorded in order to estimate time taken to complete the questionnaire for real samples. They also allowed to mark any words or sentences that are confusing or difficult for them to understand.

A Multiple Linear Regression analysis was applied in this study. Multiple Linear Regression used to estimate the linear relationship between outcome variables and more than one predictor's 
variables or covariates. The perception of students towards retailing as a career is the dependent variable in this study while the independent variables are interest, opportunity, career flexibility, and social environment. Based on the analysis, we able to report how each of the predictors influences the outcome variables and the relative of every independent variable. The steps include in analyzing data using Multiple Linear Regression are data exploration and cleaning, Simple Linear Regression, Multiple Linear Regression, checking multicollinearity and interactions, checking assumptions, and interpretation, presentation and conclusion.

\section{Research Findings}

After data exploration and cleaning, univariable analysis was done using Simple Linear Regression (SLR) and the result as shown in the table 1. Simple Linear Regression identified four unadjusted significant factors with $p$-value $<0.25$ to be included in variable selection. The factors were interest, career flexibility, opportunity and social environment.

Method of variable selection was proceeded by using step wise method. In this study, opportunity, career flexibility and social environment were the significant variable with $p<0.001$. No multicollinearity and interaction were detected in this study.

From table 2, there was a significant linear reationship between opportunity and students' perception toward retailing as a career $(p<0.001)$. Those having 1 unit increase of mean opportunity have mean students' perception toward retailing as a career increased by 0.35 . There was a significant linear reationship between career flexibily and students' perception toward retailing as a career with $(p<0.001)$. Those having 1 unit increase of mean career flexibity have mean students' perception toward retailing as a career increased by 0.29 . There was a significant linear reationship between social environment and students' perception toward retailing as a career $(p<0.001)$. Those having 1 unit increase of mean social environmnet have mean students' perception toward retailing as a career increased by 0.15 .

The normality of residuals assumption for students' perception toward retailing as a career was met as there was the bell shaped curve of the residuals. There was no peculiar shape of divergence or convergence spotted in scatter diagrams proposed the assumptions of homogeneity of variances was met.

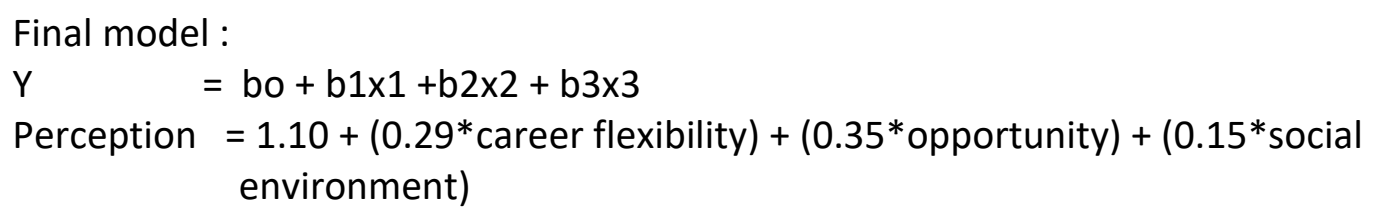


INTERNATIONAL JOURNAL OF ACADEMIC RESEARCH IN BUSINESS AND SOCIAL SCIENCES Vol. 8, No. 9, Sept. 2018, E-ISSN: 2222-6990 @ 2018 HRMARS

Table 1. Simple Linear Regression versus Multiple Linear Regression

\begin{tabular}{|c|c|c|c|c|c|c|c|}
\hline \multirow[t]{2}{*}{ VARIABLES } & \multicolumn{3}{|c|}{ Simple Linear Regression } & \multicolumn{4}{|c|}{ Multiple Linear Regression } \\
\hline & $b^{a}$ & $95 \% \mathrm{Cl}$ & $p$ value & adj. $b^{\mathbf{b}}$ & $95 \% \mathrm{Cl}$ & t-stat & $p$ value \\
\hline Opportunity & 0.67 & $\begin{array}{l}0.59 \\
0.76\end{array}$ & $<0.001$ & 0.35 & $\begin{array}{l}0.25 \\
0.45\end{array}$ & 6.82 & $<0.001$ \\
\hline $\begin{array}{l}\text { Career } \\
\text { flexibility }\end{array}$ & 0.63 & $\begin{array}{l}0.55 \\
0.70 \\
\end{array}$ & $<0.001$ & 0.29 & $\begin{array}{l}0.18, \\
0.40 \\
\end{array}$ & 5.36 & $<0.001$ \\
\hline $\begin{array}{l}\text { Social } \\
\text { environment }\end{array}$ & 0.50 & $\begin{array}{l}0.43 \\
0.57 \\
\end{array}$ & $<0.001$ & 0.15 & $\begin{array}{l}0.07 \\
0.24\end{array}$ & 3.45 & $<0.001$ \\
\hline Interest & 0.56 & $\begin{array}{l}0.47 \\
0.66 \\
\end{array}$ & $<0.001$ & & & & \\
\hline \multicolumn{8}{|c|}{$\begin{array}{l}{ }^{a} \text { Crude regression coefficient } \\
{ }^{b} \text { Adjusted regression coefficient } \\
\text { Stepwise multiple linear regression method applied. Model assumptions are fulfilled } \\
\text { No multicollinearity detected. There were no interactions amongst independent variables. } \\
\text { Coefficient of determination }\left(\mathrm{R}^{2}\right)=0.62\end{array}$} \\
\hline
\end{tabular}

Table 2. Multiple Linear Regression

\begin{tabular}{|l|l|l|l|l|}
\hline Variables & $\begin{array}{l}\text { Adjusted } \\
\beta^{\text {a }}\end{array}$ & $95 \% \mathrm{Cl}$ & t-stat & $\mathrm{p}$ value \\
\hline Opportunity & 0.35 & $0.25,0.45$ & 6.82 & $<0.001$ \\
\hline Career flexibility & 0.29 & $0.18,0.40$ & 5.36 & $<0.001$ \\
\hline Social environment & 0.15 & $0.07,0.24$ & 3.45 & $<0.001$ \\
\hline $\begin{array}{l}\text { a Multiple Linear Regression }\left(\mathrm{R}^{2}=0.62\right) \\
\text { are met) }\end{array}$ & The model reasonably fits well; model assumption \\
\hline
\end{tabular}

\section{Discussion and Conclusion}

In the study, it prescribes that the most influential factors between opportunity and students' perception towards retailing as a career. From the research, it shows that opportunity gives the most positive factors to students' perception towards retailing as a career. Based on Multiple Linear Regression, opportunity showed a result $\beta=0.35, p<0.001$. Hypothesis $(H 1)$ was accepted as there was a significant relationship between opportunity and students' perception towards retailing as a career. This is supported by the journal of "Student Perceptions of Retailing as a Destination Career" that reported the opportunities they can grab if they choose the retailing as a career. The most popular retail sector was department store with the percentage of $44.1 \%$, followed by clothing/fashion retailing that is $22.9 \%$, while the least preferred sector was DIY that is $50 \%$ and grocery were $31.3 \%$ (Broadbridge, 2003). From the journal, they also mention the reasons for choosing the large wellknown companies because it is the opportunity for those who choose the retailing as a career. The company included Marks \& Spencer, Debenhams, Arcadia, House of Fraser, Tesco, Sainsbury and Asda. Then, the students choose retailing because of the advancement and development opportunities (22.6\%) they offered, while a third reason given was actual work experience at the nominated retailer (14\%) (Broadbridge, 2003). 
The opportunity factors also supported by the journal from (Broadbridge et al., 2009) in which students can get the opportunity when they working in retail sector after graduation. They expect to have a linear career path with a good salary, wanting a good work life balance, and reflecting the notion that they want it all. They got the opportunity that enjoyment of work, good pay and reward packages that is an important engagement drivers for students. (Broadbridge et al., 2009). Others, students who had taken retail course may offer the opportunity to observe and participate in any business and variety of tasks required to service business needs. Based on the previous research, there are (52.4\%) respondents that offered the opportunity to participate in any business (Broadbridge, 2003).

Based on the interpretation of results, it addresses that there is an association between career flexibility and students' perception towards retailing as a career. Based on Multiple Linear Regression, career flexibility showed a result $\beta=0.29, p<0.001$. Hypothesis $(H 1)$ was accepted as there was a significant relationship between career flexibility and students' perception towards retailing as a career. This show that students were concerned the career flexibility available to them when working in the retail sector after graduation. Students who had taken retail course may offer the opportunity to observe and participate in any business and variety of tasks required to service business needs (Broadbridge, 2003). Retail firms must continue to work on improving many aspects of the working conditions within the industry. There are a number of areas that students believe the industry is behind other industries, particularly in regards to pay, opportunities for advancement, training and development, and working hours (Casey, 2013).

Perceptions toward retailing as a career can be a good predictor of students' career choice behaviors. They found that students normally have a relatively unfavorable image of retailing as a graduate career. Career flexibility is a concept that recognizes the fact that careers in the 21st-century economy often follow an adaptable rather than a linear progression. Out of necessity or personal choice, individuals may leave the workforce for a pass of time at any point in the life cycle, but will need or want to reenter the workforce. Other studies that reported the same results as the career flexibility one of the predictors. Based on the previous research, there are $(63.7 \%)$ respondents that agree about career flexibility is one of the factor to choose retailing as a destination career (Broadbridge, 2003). From the previous study that is from (Boreham, Lafferty, Roan, \& Whitehouse, $1996)$, their $\beta=0.471$. Then, we compared to our results that is $\beta=0.33$.

From the research, it is shown that social environment also have an association with students' perception towards retailing as a career. Based on Multiple Linear Regression, social environment showed a result $\beta=0.15, p<0.001$. Hypothesis $(H)$ was accepted as there was a significant relationship between social environment and students' perception towards retailing as a career. This is supported by the journal of "Business School Students' Career Perceptions and Choice Decisions" which is there is retail internship experience among the student is, $21.7 \%, 12.5 \%$ had a retail full-time experience and $50.0 \%$ had a retail part-time experience. Having a retail internship positively pretentious interest in following a retail career and helped students to decide a retail career (Miller, 2011). 
Then, based on the journal from Safiek Mokhlis that is "Marketing students' perception of retailing as a career option", it said that the 2 most influential personal sources that affected career choices decision is parents and friend/relative working in the field. (Mokhlis \& TERENGGANU, 2014). Parents were also influential people in helping students decide on a career. In the other journal that is "Student Perception toward Retailing as a Destination Career" also shows the positive results that are career talk from companies had some influence that is just $16.7 \%$ of final year students had attended such presentations. Few respondent with $29.2 \%$ considered that previous work experience had positive that can influence their intentions to pursue a career in retailing. Personal experience had raised awareness of the image and career opportunities available in retailing. (Broadbridge, 2003).

\section{Corresponding Author}

Mardhiah binti Kamaruddin, Faculty of Entrepreneurship and Business, Universiti Malaysia Kelantan, Malaysia, Email: mardhiah.k@umk.edu.my

\section{References}

Broadbridge, A. (2003). Student perceptions of retailing as a destination career. International Journal of Retail \& Distribution Management, 31(6/7), 298.

Broadbridge, A. M., Maxwell, G. A., \& Ogden, S. M. (2009). Selling retailing to Generation Y graduates: recruitment challenges and opportunities. The International Review of Retail, Distribution and Consumer Research, 19(4), 405-420.

Christensen, K. (2013). Launching the workplace flexibility movement: Work family research and a program of social change. Community, Work \& Family, 16(3), 261-284.

Isaac, I., \& Roger, B. (2016). The role of individual interpersonal relationships on work performance in the South African retail sector.

Lindblom, A., Lindblom, A., Kajalo, S., Kajalo, S., Mitronen, L., \& Mitronen, L. (2016). Does a retailer's charisma matter? A study of frontline employee perceptions of charisma in the retail setting. Journal of Services Marketing, 30(3), 266-276.

Miller, D. (2011). Career opportunities in retailing: Developing tomorrow's retail leaders: New York, NY: McGraw-Hill.

Mokhlis, S. (2014a). The image of retailing as a graduate career: Evidence from Malaysia. International Business Management, 8(2), 146-152.

Mokhlis, S. (2014b). Predicting Students' Intent to Pursue Retailing as a Career: A Means-End Perspective. Mediterranean Journal of Social Sciences, $5(27$ P1), 404. 
INTERNATIONAL JOURNAL OF ACADEMIC RESEARCH IN BUSINESS AND SOCIAL SCIENCES

Vol. 8, No. 9, Sept. 2018, E-ISSN: 2222-6990 @ 2018 HRMARS

Mokhlis, S., \& Terengganu, K. (2014). Marketing students' perception of retailing as a career option. The Social Sciences, 9(6), 486-491.

Renko, S., Rasic, S., \& Petljak, K. (2016b). STUDENTSPERCEPTION ON THE ROLE OF HIGH EDUCATION IN IMPROVING IMAGE OF RETAILING AS A CAREER. Economic and Social Development: Book of Proceedings, 136. 